AKRUAL 1 (2) (2010): 190-214 $e$-ISSN: 2502-6380

\title{
AKRUAL
}

Jurnal Akuntansi

http://fe.unesa.ac.id/ojs/index.php/akrl

\section{PELAPORAN BIAYA LINGKUNGAN SEBAGAI ALAT BANTU BAGI PENGAMBILAN KEPUTUSAN YANG BERKAITAN DENGAN PENGELOLAAN LINGKUNGAN}

\author{
Dian Agustia \\ Universitas Airlangga \\ Email: agustia.dian@yahoo.com \\ Artikel diterima: 1 Februari 2010 \\ Revisi terakhir: 9 Maret 2010
}

\begin{abstract}
Environmental accounting is a term associated with the inclusion of environmental costs into corporate accounting practices. The proportion of environmental costs is $20 \%$ of total operational costs company. Environmental costs are grouped in environmental media, among others: (a) water / climate, (b) Wastewater, (c) waste, (d) soil/groundwater, $(e)$ noise / vibration, $(f)$ biodiversity/landscape, $(g)$ radiation. Classification of environmental media is based on United Nations Statistics Division publication entitled Integrated Environmental and Economic Accounting. The media environment is represented categories of environmental impacts caused to nature.
\end{abstract}

Keywords: Environmental accounting

\section{PENDAHULUAN}

Lingkungan hidup sebagai suatu ekosistem memiliki mekanisme yang mampu mempertahankan keseimbangannya. Setiap terjadi ketidakseimbangan di dalam ekosistem, maka lambat laun akan pulih dengan sendirinya karena alam memang memiliki kemampuan untuk memperbaiki dirinya dengan siklus-siklus biologi yang terjadi di dalamnya. Namun fakta yang ada pada saat ini adalah ada begitu banyak kerusakan lingkungan yang tidak dapat pulih dengan sendirinya. Kerusakan tersebut antara lain disebabkan oleh limbah yang mencemari tanah, air, dan udara.

Perusahaan manufaktur di dalam operasinya selain menghasilkan produk, juga menghasilkan limbah. Hal ini terjadi karena adanya inefisiensi dalam operasi perusahaan tersebut. Konsep mengenai pengelolaan lingkungan yang dipahami perusahaan adalah pengelolaan limbah, atau yang lebih dikenal dengan pendekatan end of pipe. Pendekatan ini terbatas pada pengelolaan limbah yang sudah dikeluarkan oleh perusahaan tanpa adanya pemikiran untuk mengubah proses produksi agar limbah yang dikeluarkan oleh perusahaan dapat dikurangi. Dalam berbagai penelitian 
yang telah dilakukan terbukti bahwa di masa yang akan datang perusahaan akan mengeluarkan biaya yang makin lama akan makin besar hanya untuk pengelolaan limbah saja. Dengan begitu banyaknya perusahaan manufaktur yang berdiri, maka permasalahan limbah tidak dapat dipandang sebelah mata. Hal ini terjadi karena banyak perusahaan manufaktur yang tidak memperdulikan masalah lingkungan karena yang menjadi tujuan utama operasi perusahaan adalah untuk memperoleh keuntungan saja. Konsep ekoefisiensi diperkenalkan oleh WBCSD (World Business Council for Sustainable Development) pada tahun 1992 (WBCSD, 2000:2) dan sejak saat itu telah banyak digunakan oleh berbagai negara untuk dapat terus melangsungkan bisnisnya tanpa merusak lingkungan. WBCSD menyatakan sebagai berikut:

Eco-efficiency is achieved by the delivery of competitively-priced goods and services that satisfy human needs and bring quality of life, while progressively reducing ecological impacts and resource intensity throughout the life-cycle to a level at least in line with the earth's estimated carrying capacity (WBCSD, 2000: 9).

Hansen dan Mowen (2005:70) juga menyatakan bahwa yang menjadi inti konsep ekoefisiensi adalah "mempertahankan bahwa organisasi dapat memproduksi barang dan jasa yang lebih bermanfaat sambil secara simultan mengurangi dampak lingkungan yang negatif, konsumsi sumber daya, dan biaya." Selain itu juga diadakan berbagai konferensi tingkat internasional yang membahas mengenai permasalahan lingkungan.

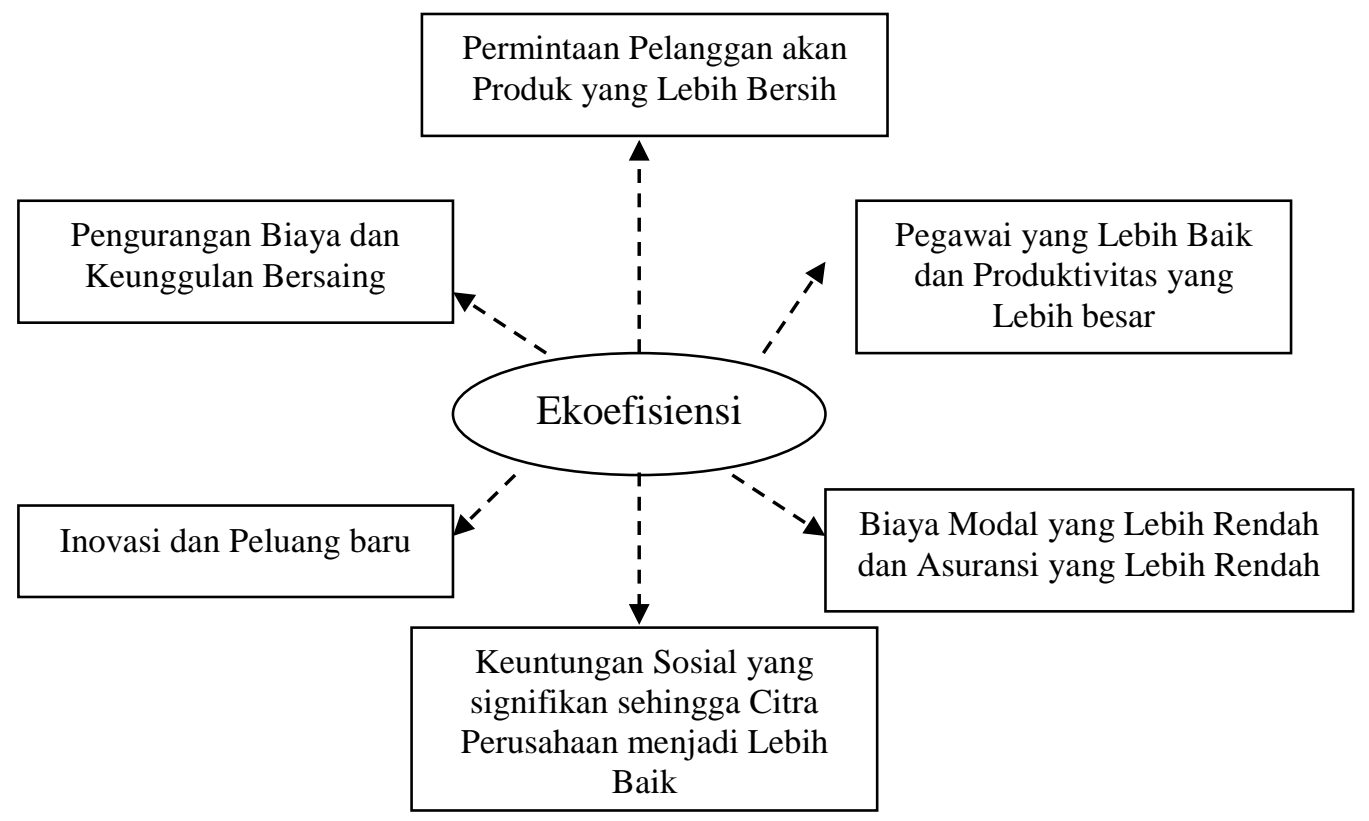

Sumber: Don R. Hansen \& Maryanne M. Mowen. 2007. Akuntansi Manajemen, Buku 2. edisi ke-7. Jakarta. Salemba Empat. Hal. 71 


\section{Gambar 1. Penyebab-Penyebab dan Insentif untuk Ekoefisiensi}

Konsep ekoefisiensi ini, Hansen dan Mowen (2005: 71) merumuskan enam hal yang menjadi sumber penyebab dan insentif untuk ekoefisiensi. Keenam hal tersebut adalah:

1. Pelanggan menginginkan produk yang ramah lingkungan.

2. Pegawai memiliki preferensi untuk lebih nyaman bekerja di dalam perusahaan yang bertanggung jawab terhadap lingkungan.

3. Perusahaan yang bertanggung jawab terhadap lingkungan memperoleh keuntungan eksternal seperti keringanan biaya modal.

4. Kinerja lingkungan yang lebih baik dapat menghasilkan keuntungan sosial.

5. Perusahaan termotivasi untuk mencari peluang-peluang baru dalam hal desain produk, atau penentuan target pemasaran mereka.

6. Efektifitas biaya yang mengakibatkan perusahaan menjadi lebih unggul dan daya saingnya bertambah.

Ada pergeseran orientasi perusahaan yang sebelumnya hanya bertujuan untuk meningkatkan laba, kini memiliki tujuan baru, yaitu pengembangan yang berkesinambungan atau disebut juga sebagai sustainable development, yang didefinisikan sebagai pengembangan yang memenuhi kebutuhan saat ini tanpa mengurangi kemampuan generasi masa depan untuk memenuhi kebutuhan mereka sendiri (Hansen \& Mowen, 2007:70). Di dalam Handbook of National Accounting, Integrated Environmental and Economic Accounting 2003 (http://unstats.un.org/unsd/envAccounting/seea2003.pdf) dinyatakan mengenai tiga pilar sustainable development sebagai berikut:

A widely held view of sustainable development is that it refers at once to economic, social and environmental needs. According to this view there must be no single focus (or object) of sustainability, but instead all of the economic, social and environmental systems must be simultaneously sustainable in and of themselves. Satisfying any one of these three sustainability "pillars" without also satisfying the others is deemed insufficient for the following reasons. First, each of the three pillars is independently crucial. Second, each of the three pillars is urgent and little time is available for debating which one should be addressed first; they must therefore be addressed simultaneously. Finally, the three pillars are interconnected. There is, therefore, a risk of unwittingly causing (or worsening) problems in one system while attempting to correct problems in another.

Berdasarkan kutipan tersebut, ada tiga bagian penting di dalam sustainable development dan kedudukannya sejajar sehingga semuanya harus menjadi prioritas bagi perusahaan. Akuntansi konvensional sebagai suatu sistem yang menghasilkan informasi yang dibutuhkan dalam proses pengambilan keputusan oleh manajemen dianggap tidak memadai untuk menjawab permasalahan lingkungan karena biaya dan pendapatan lingkungan tidak dapat diidentifikasi oleh sistem tersebut. Sistem akuntansi perlu diubah, atau perusahaan perlu menggunakan pendekatan lain untuk 
menghasilkan informasi akuntansi terkait dengan pengelolaan lingkungan. Selain itu, dalam lingkup internasional sudah ada berbagai aturan yang mengatur mengenai tanggung jawab lingkungan yang dimiliki perusahaan. Diantaranya adalah ISO 14000 yang mengatur mengenai standar sistem manajemen lingkungan yang dapat diterapkan oleh perusahaan yang peduli terhadap lingkungan.

Pelestarian lingkungan dan kehidupan sosial masyarakat bukan hanya tanggung jawab pemerintah tetapi semua pihak, termasuk perusahaan. Perusahaan diharapkan menjaga keseimbangan antara mencari keuntungan, menjaga kelestarian lingkungan dan kehidupan masyarakat. Secara keseluruhan, sampai saat ini, usaha untuk menuju perbaikan kualitas lingkungan yang dilakukan oleh perusahaan bervariasi. Dari sekian banyak penelitian, baik di negara maju maupun di negara berkembang, ternyata niat perusahaan untuk mengalokasikan dana perusahaan untuk biaya sosial (di dalamnya termasuk untuk lingkungan) masih sangat kurang.

Pada tahun 2001, PBB menerbitkan suatu prosedur dan prinsip mengenai akuntansi pengelolaan lingkungan, atau yang populer dengan istilah EMA (Environmental Management Accounting) (United Nations Division of Sustainable Development, 2001). Publikasi PBB yang bertajuk: Environmental Management Accounting: Procedures and Principles berisi berbagai terminologi dan teknik yang bertujuan untuk mengembangkan pemahaman umum mengenai konsep mendasar mengenai EMA. EMA sendiri adalah suatu pendekatan yang dapat digunakan oleh perusahaan untuk pengelolaan lingkungan, dan mampu melakukan apa yang tidak dapat dilakukan oleh akuntansi konvensional dalam hal identifikasi biaya biaya lingkungan, dan menggunakan informasi itu untuk pengambilan keputusan internal perusahaan karena EMA adalah bagian dari akuntansi manajemen, sehingga tidak ada format baku dalam aplikasinya. Hal ini juga dinyatakan oleh IFAC (International Federation of Accountants) sebagai berikut:

"It makes sense that different countries and organizations would adapt general EMA concepts, language and practices to suit their own goals. A certain amount of experimentation and variation is also to be expected because EMA is still a relatively young and emerging field in comparison to conventional management accounting" (IFAC, 2005: 5)

Ada beberapa alasan mengapa EMA dikembangkan pada tahun tahun terakhir ini:

1. Adanya kebutuhan untuk efisiensi operasional dan bahan baku yang digunakan dalam proses produksi.

2. Meningkatnya biaya bahan mentah, pengelolaan limbah, aturan pemerintah, dan potensi kewajiban.

3. Semakin besarnya tekanan yang dihadapi oleh perusahaan karena perusahaan dituntut untuk meningkatkan kinerja lingkungannya.

4. Adanya batasan pendekatan akuntansi manajemen konvensional dalam menghadapi tuntutan akan efisiensi dan biaya yang berkaitan dengan lingkungan. 


\section{PEMBAHASAN}

\section{Akuntansi Pengelolaan Lingkungan (Environmental management Accounting)}

Isu mengenai akuntansi lingkungan telah berkembang dalam dua puluh tahun terakhir, dan sejak saat itu ada beragam persepsi yang berkembang mengenai konsep akuntansi lingkungan. Karena ada banyak pihak yang membutuhkan informasi lingkungan yang terkait dengan perusahaan, ada beragam pedekatan dan alat yang dikembangkan dalam ruang lingkup akuntansi lingkungan untuk memenuhi kebutuhan informasi ini. Ada dua kelompok utama di dalam dampak-dampak lingkungan yang berkaitan dengan perusahaan (Burrit, 2001), (1). Dampak lingkungan terhadap sistem ekonomi, yang disebabkan oleh perusahaan (environmentally induced impacts of companies on their economic system), (2). Dampak terhadap sistem lingkungan yang terkait dengan perusahaan (company related impacts on environmental system)

Dampak yang pertama dapat diketahui melalui monetary environmental information. Informasi ini digambarkan dalam satuan mata uang. Beberapa contoh informasi lingkungan yang dapat dikategorikan dalam monetary environmental information adalah: pembiayaan untuk produksi yang bersih, denda pelanggaran hukum lingkungan, nilai aset lingkungan. Dampak yang kedua dapat diketahui melalui physical environmental information. Informasi ini menggunakan satuan unit. Contohnya adalah: jumlah energi yang digunakan tiap unit produk, jumlah bahan yang digunakan. Akuntansi konvensional juga menyediakan informasi terpisah mengenai aspek keuangan dan non keuangan dari aktivitas perusahaan, yaitu: akuntansi manajemen konvensional, akuntansi keuangan konvensonal, dan sistem akuntansi lain, sistem perencanaan produksi, sistem akuntansi persediaan, dan sistem kualitas.

Beberapa pihak memiliki perhatian besar terhadap dampak fisik lingkungan dari aktivitas perusahaan, sementara juga ada stakeholder lain yang tertarik dengan dampak keuangan yang terjadi sebagai akibat dari dampak lingkungan yang ditimbulkan oleh perusahaan. Contohnya adalah, para pemegang saham tertarik dengan nilai keuangan perusahaan, dan tidak begitu ingin tahu mengenai laporan terpisah yang dibuat perusahaan yang berisi tentang informasi polusi yang dinyatakan dalam satuan unit. Pemegang saham tertarik dengan informasi yang berkaitan dengan nilai saham mereka. Sememntara itu, lembaga perlindungan lingkungan tertarik dengan besarnya polusi dan limbah yang diukur dalam satuan unit.

Perbedaan utama antara akuntansi konvensional dan akuntansi lingkungan adalah bahwa sistem akuntansi lingkungan secara jelas menggambarkan dan memperhitungkan dampak dampak lingkungan yang berkaitan dengan perusahaan (Burrit, 2001). Di dalam pendekatan konvensional, perbedaan antara akuntansi konvensional dan akuntansi lingkungan tidak begitu jelas. Terlebih lagi, perbedaan di dalam unit pengukuran, kualitas data dan sumber sumbernya, tidak dapat diabaikan bila perusahaan ingin menyajikan informasi yang sesuai dengan tujuan stakeholder.

Sistem akuntansi lingkungan moneter (monetary environmental accounting) mengukur dampak lingkungan terhadap sistem ekonomi, yang disebabkan oleh 
perusahaan dalam satuan mata uang. Sistem ini dapat dikatakan sebagai perluasan ruang lingkup akuntansi konvensional. Sedangkan sistem akuntansi lingkungan fisik (physical environmental accounting) menggambarkan dampak terhadap sistem lingkungan yang terkait dengan perusahaan. Kedua sistem ini dibuat untuk memenuhi kebutuhan informasi yang semakin bertambah dari stakeholder internal dan eksternal. Bila dijadikan satu, akuntansi lingkungan fisik dan moneter membentuk akuntansi lingkungan.

Alasan EMA dikembangkan adalah karena ada pengenalan kebutuhan mengenai adanya keterbatasan pendekatan akuntansi manajemen konvensional untuk aktivitas dan keputusan manajemen yang melibatkan biaya lingkungan yang signifikan dan/atau dampak lingkungan yang signifikan (Hazardous Waste Consultant, 2005). Aktivitas manajemen yang dapat memperoleh manfaat dari EMA adalah desain proses dan produk, alokasi dan pengendalian biaya, penganggaran modal, pembelian, manajemen rantai supply, pemberian harga pada produk, dan evaluasi kinerja. Pengambil keputusan yang ada di dalam perusahaan dapat menggunakan informasi aliran fisik dan informasi biaya yang disediakan melalui EMA untuk membuat keputusan yang mempengaruhi kinerja lingkungan dan keuangan bagi organisasi. Jadi, EMA bukan hanya menjadi salah satu dari alat pengukuran manajemen lingkungan, tetapi merupakan suatu konsep luas mengenai prinsip prinsip dan pendekatan pendekatan yang menyediakan alur bahan/energi dan informasi biaya yang menentukan keberhasilan aktivitas manajemen lingkungan. Manfaat lain yang dapat diambil dari penerapan EMA adalah identifikasi peluang pengurangan biaya, keputusan yang lebih baik dalam hal bauran produk dan harga produk, menghindari biaya yang akan timbul di masa yang akan datang melalui keputusan investasi yang lebih baik, dan justifikasi keuangan untuk inisiatif lingkungan.

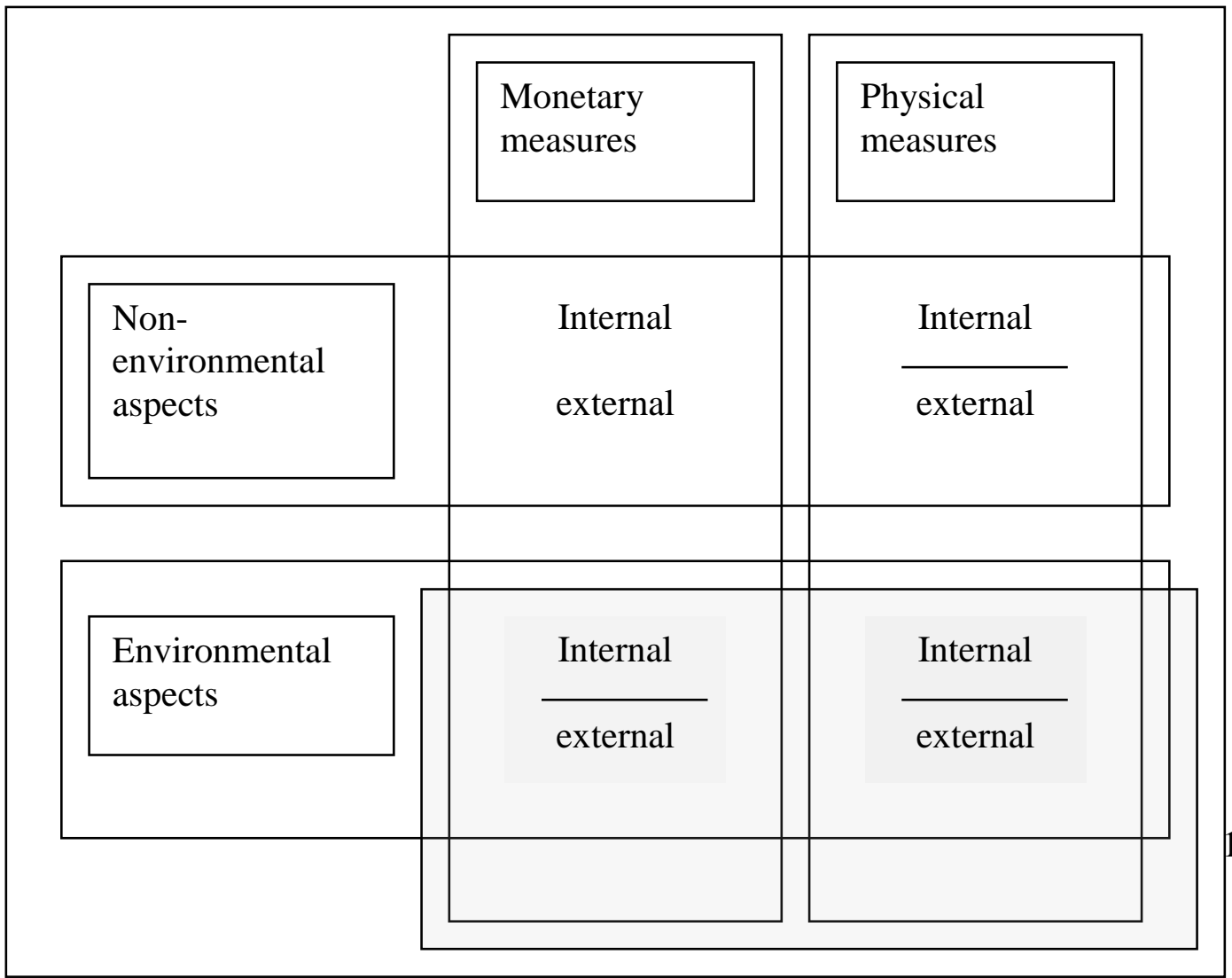


Sumber: Roger L Burrit, Tobias Hahn, dan Stefan Schaltegger. 2001. Current Developments in Environmental Management Accounting - Towards a Comprehensive Framework for Environmental Management Accounting.

\section{Gambar 2. Ruang lingkup dan gambaran akuntansi lingkungan}

Menurut Hazardous Waste Consultant (2005), manfaat EMA dapat dikategorikan menjadi tiga, yaitu: (1). Compliance efficiency - Cost-effective compliance with environmental regulations and corporate policies, (2). Eco-efficiency - Simultaneous cost savings and environmental impact reductions as energy, water, and materials are used more efficiently; and (3). Strategic Position - Developing and implementing effective and environmentally sensitive programs to ensure an organization's long term strategic position.

Perusahaan dapat memilih penggunaan pendekatan EMA yang berbeda berdasarkan sumber daya yang tersedia dan pengalaman di masa lampau perusahaan tersebut dengan EMA. Konsep penting yang ada di dalam EMA menurut EMARIC (www.emawebsite.org) adalah: (1). EMA focuses on costs internal to the company; EMA does not include external costs to individuals, society, or the environment for which a company is not legally held responsible, (2). EMA places particular emphasis on accounting for environmental costs, (3). EMA encompasses not only environmental and other cost information, but also explicit information on physical flows and fates of materials and energy, (4). EMA information can be used for most types of management activity or decision-making within an organization, but is particularly useful for proactive environmental management activities.

\section{Akuntansi dan Lingkungan}

Perusahaan atau bisnis menghadapi banyak tekanan dalam hal lingkungan seperti yang ada di dalam Gambar berikut, dari berbagai tekanan yang dihadapi perusahaan tersebut, dapat dibedakan menjadi 2 kategori, yaitu yang berkaitan dengan peraturan (legislative), dan orientasi pasar (market-based). 


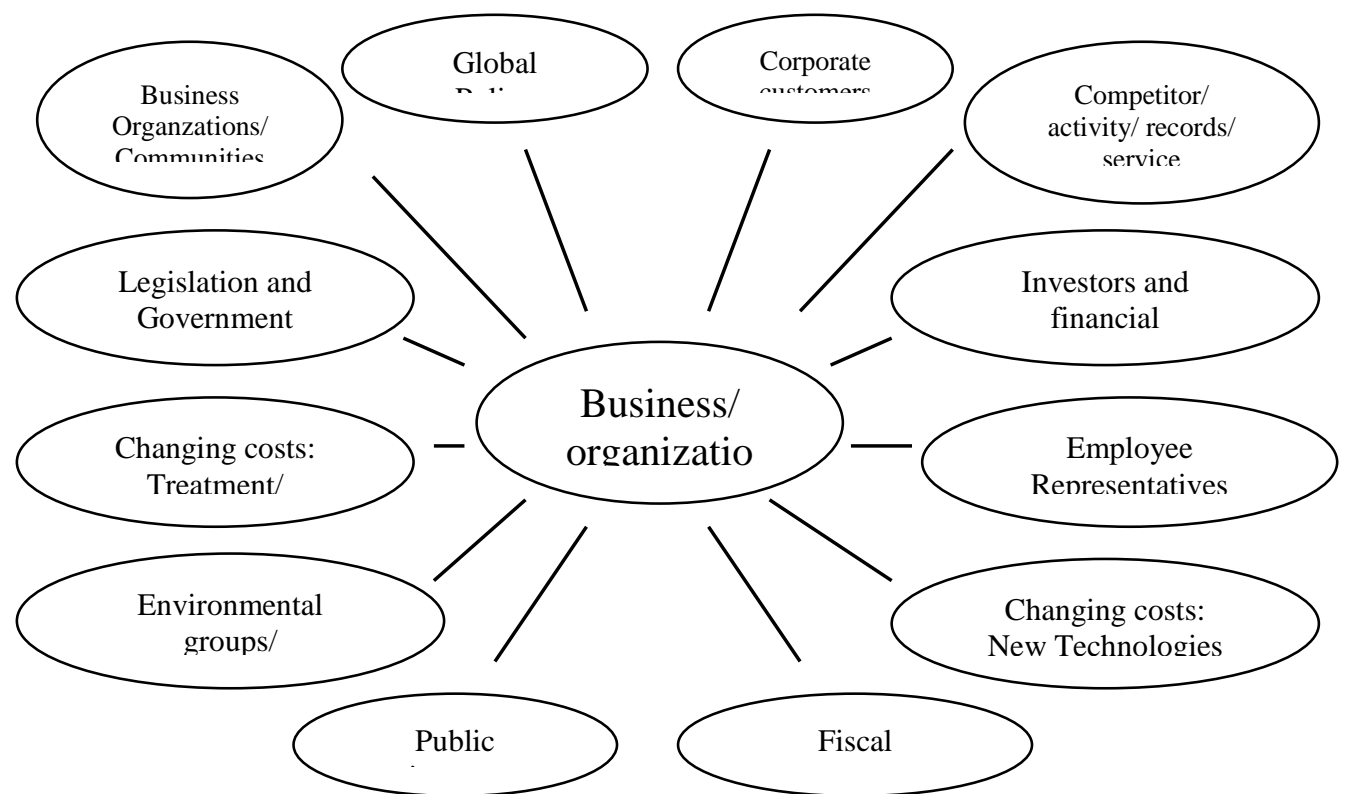

Sumber: Rob Gray dan John Bebbington. 2001. Accounting for the Environment. $2^{\text {nd }}$ edition. London.

Sage Publication. hlm. 5

\section{Gambar 3. Sumber Sumber Tekanan Lingkungan: Peluang dan Ancaman}

Perspektif yang konvensional, lingkungan yang tercakup di dalam sistem akuntansi perusahaan disebut sebagai lingkungan subtantif, yang oleh Gray dinyatakan sebagai berikut: “...'substantive environment" is bounded with reference to only those events which the accountant traditionally recognizes - those economic events which can be described in financial terms" (Gray, 2001:22).

Perusahaan mengambil sumber daya alam baik yang dapat diukur dan yang tidak dapat diukur dengan uang. Model akuntansi konvensional tidak dapat mengenali interaksi interaksi ini sehingga pada akhirnya sama sekali diabaikan.

Hal hal yang terukur oleh akuntansi konvensional sangat terbatas pada hal hal yang dapat diukur dengan uang, atau ditukar dengan uang. Karena akuntansi merupakan sumber informasi yang sangat penting bagi perusahaan, maka kekurangan ini sangat berbahaya. Informasi yang dihasilkan oleh sistem akuntansi digunakan dalam keputusan manajemen yang memiliki cakupan yang luas, dan juga menjadi sumber informasi utama bagi pihak eksternal yang memiliki kepentingan terhadap kinerja perusahaan.

\section{Akuntansi Lingkungan}

Konsep akuntansi lingkungan sebenarnya sudah mulai berkembang sejak tahun 1970-an di Eropa. Hal ini terjadi sebagai akibat dari tekanan lembaga-lembaga bukan pemerintah dan meningkatnya kesadaran lingkungan di kalangan masyarakat yang mendesak agar perusahaan-perusahaan menerapkan pengelolaan lingkungan bukan hanya kegiatan industri demi bisnis saja karena pada waktu itu perusahaan perusahaan hanya berorientasi laba yang tinggi.

Akuntansi lingkungan adalah istilah yang berkaitan dengan dimasukkannya biaya lingkungan ke dalam praktek akuntansi perusahaan. Banyak perusahaan industri dan jasa besar dunia yang kini menerapkan akuntansi lingkungan. Tujuannya adalah untuk meningkatkan efisiensi pengelolaan lingkungan dengan melakukan penilaian kegiatan lingkungan dari sudut pandang biaya dan manfaat. Akuntansi 
lingkungan diterapkan oleh berbagai perusahaan untuk menghasilkan informasi tentang biaya dan manfaat perlindungan lingkungan.

Sebagai alat bagi pengambilan keputusan manajemen, akuntansi lingkungan digunakan untuk menilai keefektifan kegiatan yang berorientasi lingkungan berdasarkan ringkasan dan klasifikasi biaya konservasi lingkungan. Informasi akuntansi lingkungan juga digunakan untuk menemukan biaya fasilitas pengelolaan lingkungan, biaya konservasi lingkungan keseluruhan dan juga investasi yang diperlukan untuk kegiatan manajemen lingkungan. Selain itu akuntansi lingkungan juga digunakan untuk menilai efektivitas aktivitas yang berkaitan dengan lingkungan yang diperoleh tiap tahun untuk menjamin perbaikan kinerja lingkungan yang harus berlangsung terus-menerus.

Menurut Gray (2001: 7) akuntansi lingkungan mencakup: akuntansi untuk resiko dan hutang kontijensi, akuntansi untuk revaluasi aset dan proyeksi modal, analisis biaya pada area-area penting seperti energi, limbah, dan perlindungan lingkungan, pengajuan investasi yang melibatkan faktor faktor lingkungan, pengembangan sistem akuntansi dan sistem informasi baru yang mencakup semua area kinerja lingkungan, mengukur biaya dan manfaat program pengembangan lingkungan, dan mengembangkan teknik-teknik akuntansi yang menyatakan aset, hutang dan biaya di dalam kerangka ekologis. 


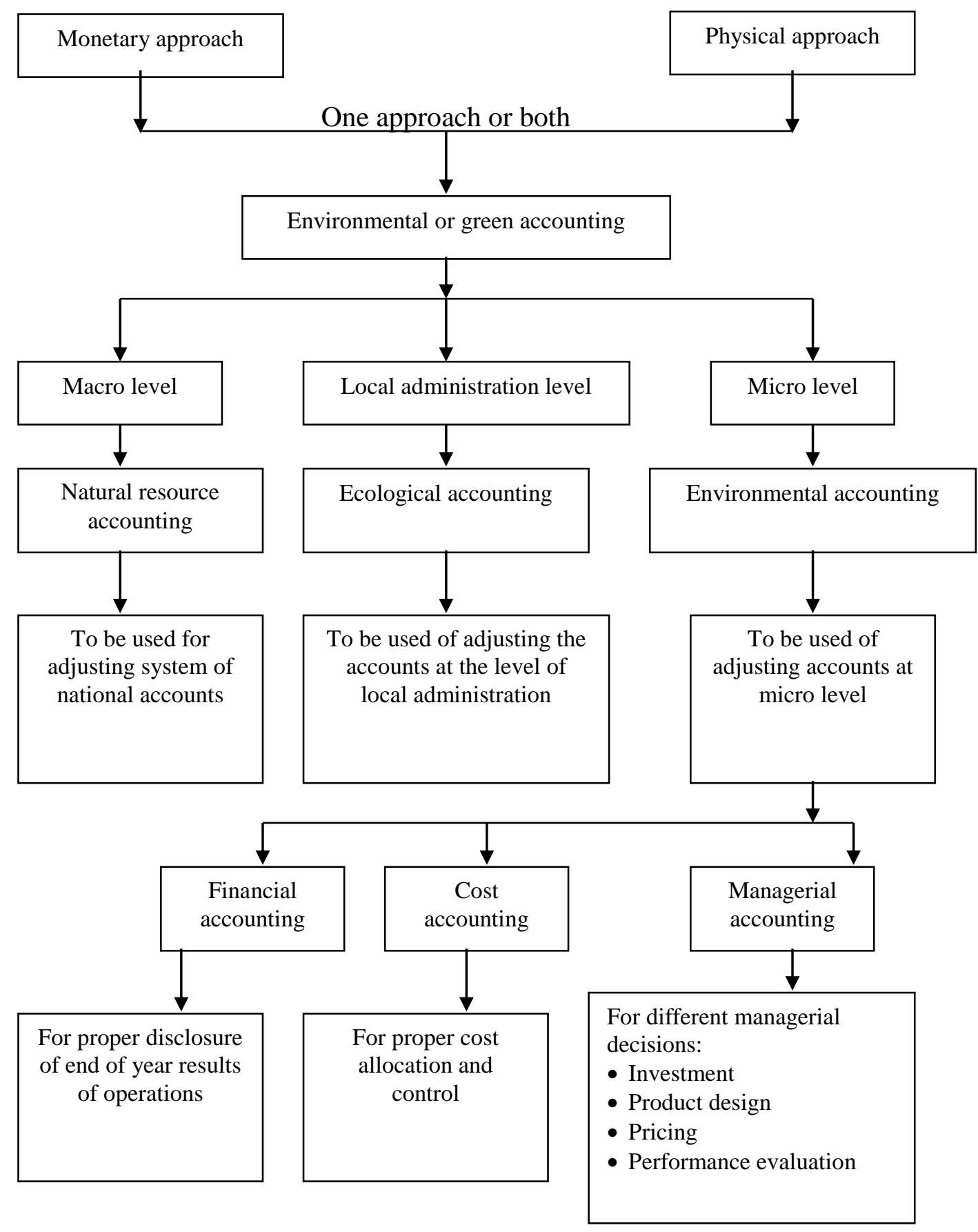

Sumber: Hamid, Mohamed A Raouf A. 2002. Theoretical Framework for Enviromental Accounting-Application on the Egyptian Petroleum Sector. Cairo. The Egyptian Forum on Environment \& Sustainable Development (EFESD). hlm. 8

Gambar 4. Pendekatan dan klasifikasi akuntansi lingkungan 
Ada berbagai macam pendekatan mengenai akuntansi lingkungan yang dibahas di dalam literatur, diantaranya adalah seperti yang ada pada Gambar tersebut. Selain itu juga ada dua macam pendekatan di dalam akuntansi, yaitu pendekatan moneter dan fisik, keduanya tercakup di dalam akuntansi lingkungan yang dapat dibagi menjadi tiga macam berdasarkan cakupannya, yaitu tingkat makro, tingkat administrasi lokal, dan tingkat mikro, atau yang sama seperti tingkat perusahaan. Secara lebih spesifik, akuntansi lingkungan pada tingkat perusahaan digambarkan memiliki empat pendekatan yang berbeda seperti pada Gambar berikut:

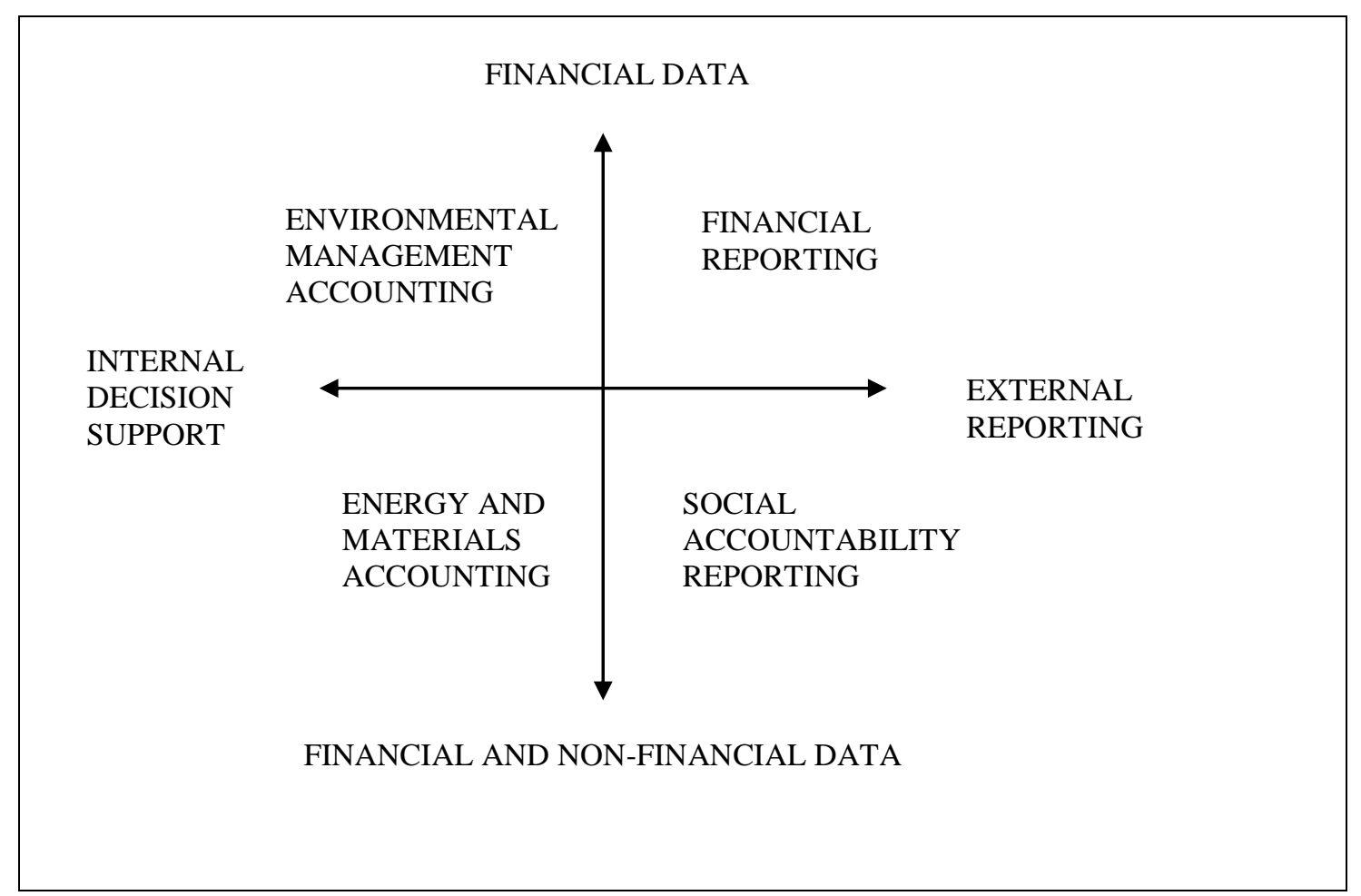

Sumber: Mateo Bartolomeo, Martin Bennet, Jan Jaap Bourma, Peter Heydkamp, Peter James, Tewn Wolters. 2000:33)Environmental Management Accounting in Europe: Current Practice and Future Potential. The European Accounting Review. hlm. 33

\section{Gambar 5. Empat pendekatan di dalam akuntansi lingkungan pada tingkat perusahaan}

Pendekatan yang pertama adalah pelaporan keuangan eksternal, dimana aspek yang berkaitan dengan lingkungan berkaitan dengan pengukuran dampak keuangan faktor-faktor lingkungan yang ada di dalam perusahaan, dalam rangka untuk memberi informasi kepada investor kreditor, dan stakeholder keuangan lainnya. Yang kedua adalah pelaporan akuntabilitas sosial, yang bertujuan untuk memperlebar ruang lingkup akuntansi dari bentuknya yang tradisional dan berorientasi kepada stakeholder keuangan menjadi suatu bentuk pertanggungjawaban kepada masyarakat yang lebih luas. Yang ketiga adalah akuntansi energi dan bahan (materials) yang 
menjadi data utama bagi penilaian daur hidup (life cycle assessment). Yang terakhir adalah akuntansi pengelolaan lingkungan.

Keputusan bisnis yang dapat didukung oleh akuntansi lingkungan adalah desain produk, desain proses, penempatan fasilitas, pembelian, pembebanan harga produk dan biaya proses, manajemen risiko/hutang, perencanaan strategis, pemilihan pemasok, pembenaran program lingkungan, investasi modal, pengendalian biaya, pengelolaan limbah, alokasi biaya, retensi produk, evaluasi kinerja, ekspansi fasilitas perusahaan.

\section{Manajemen Biaya Lingkungan}

Penghitungan biaya lingkungan penuh (full environmental costing) adalah pembebanan semua biaya lingkungan baik yang bersifat privat maupun sosial ke produk. Penghitungan biaya prifat penuh (full private costing) adalah pembebanan biaya privat ke produk individual. Biaya privat dapat dibebankan dengan menggunakan data yang dihasilkan di dalam perusahaan. Sedangkan biaya penuh memerlukan pengumpulan data yang dihasilkan di luar perusahaan, dari pihak ketiga. Setelah itu, pembebanan biaya produk mungkin dapat diperluas dan mengimplementasikan pendekatan yang disebut penilaian biaya siklus hidup (lifecycle cost assessment). Informasi yang diperoleh dapat mengarah ke desain produk dan proses alternatif yang lebih ramah lingkungan, juga dapat diketahui apakah suatu produk menguntungkan atau tidak. Peluang perbaikan tersedia luas, namun pengetahuan tentang biaya produk lingkungan merupakan kuncinya.

Akuntansi biaya lingkungan menunjukkan biaya riil atas input dan proses bisnis serta memastikan adanya efisiensi biaya. Selain itu juga dapat diaplikasikan untuk mengukur biaya kualitas dan jasa (Sri Astuti, 2002: 59). Dalam kebanyakan sistem akuntansi, biaya lingkungan disembunyikan di dalam overhead. Klasifikasi biaya lingkungan yang dilakukan itu pun bukan merupakan hal yang mudah untuk dilakukan karena akuntansi memiliki kerterbatasan dalam pengukuran biaya biaya yang berkaitan dengan lingkungan. Gray menyatakan bahwa yang perlu dilakukan oleh perusahaan adalah mengukur dampak dampak lingkungan yang bernilai material bagi perusahaan, dan perusahaan dapat mempengaruhi kondisi tersebut secara signifikan.

Kinerja lingkungan merupakan salah satu pengukuran keberhasilan bisnis. Biaya lingkungan dan kinerja lingkungan dipertimbangkan oleh manajemen dengan alasan sebagai berikut: (Bringer, 1994, dalam Sri Astuti, 2002: 59) (1). Beberapa biaya lingkungan secara signifikan mampu mengurangi atau mengeliminasi keputusan bisnis, (2). Biaya lingkungan mungkin ditunjukkan di dalam biaya overhead, atau bahkan diabaikan, (3). Beberapa perusahaan telah menemukan biaya lingkungan yang dapat ditutup kerugiannya oleh penghasilan yang digeneralisasikan melalui penjualan bahan sisa, (4). Manajemen biaya lingkungan yang lebih baik dapat dihasilkan dalam kinerja lingkungan yang lebih baik dengan keuntungan yang signifikan terhadap kesehatan masyarakat, (5). Pemahaman kinerja dan biaya lingkungan lebih dapat mencerminkan perhitungan biaya dan harga yang akurat dan dapat membantu 
perusahaan dalam mendesain proses lingkungan di masa mendatang dengan lebih baik, (6). Competitive advantage dapat dihasilkan dari proses lingkungan yang baik, (7). Akuntansi untuk biaya lingkungan dan kinerjanya dapat mendukung perkembangan perusahaan dan operasi perusahaan atas sistem manajemen lingkungan. 


\section{Pengertian EMA}

Banyak pengertian mengenai EMA, diantaranya adalah: definisi dari EMARIC (www.emawebsite.org) menyatakan: "EMA can be defined as the identification, collection, estimation, analysis, internal reporting, and use of materials and energy flow information, environmental cost information, and other cost information for both conventional and environmental decision making within an organization".

Selain itu, The Department of the Environment and Heritage Pemerintahan Australia yang mendefinisikan bahwa:

"EMA involves the more transparent accounting of environment related costs within an organization's management accounting system. Management accounting system has the purpose of providing cost information for internal management use in decisions such as cost management, product pricing and investment appraisal. EMA mainly focuses on identifying the private environmental costs that would normally be captured within an organizations accounting system. Often these environmental costs are lost in general overhead accounts and therefore not focused on by management."

IFAC (2005: 19) mendefinisikan bahwa EMA adalah:

"The management of environmental and economic performance through the development and implementation of appropriate environment-related accounting systems and practices. While this may include reporting and auditing in some companies, environmental management accounting typically involves life cycle costing, full cost accounting, benefits assessment, and strategic planning for environmental management."

United Nations Division for Sustainable Development menyatakan bahwa EMA adalah:

".... Represents a combined approach which provides for the transition of data from financial accounting and cost accounting to increase material efficiency, reduce environmental impact and risk and reduce costs of environmental protection." (2001: 8$)$

Ada bermacam macam definisi EMA, namun pada intinya adalah memperbaiki sistem akuntansi manajemen sehingga akuntansi manajemen dapat mengukur biayabiaya yang terkait dengan lingkungan yang bertujuan untuk memampukan diambilnya keputusan yang lebih baik dalam pengelolaan biaya biaya ini dan dapat terintegrasi ke dalam pengambilan keputusan operasional dan strategis. Sementara itu, EMA menyediakan suatu mekanisme untuk mengidentifikasi dan mengukur seluruh biaya lingkungan dalam proses produksi yang sedang berjalan dan manfaat ekonomis dari pencegahan polusi atau proses produksi yang lebih bersih, dan untuk mengintegrasikan semua biaya dan manfaat ini ke dalam proses pengambilan keputusan sehari-hari. 


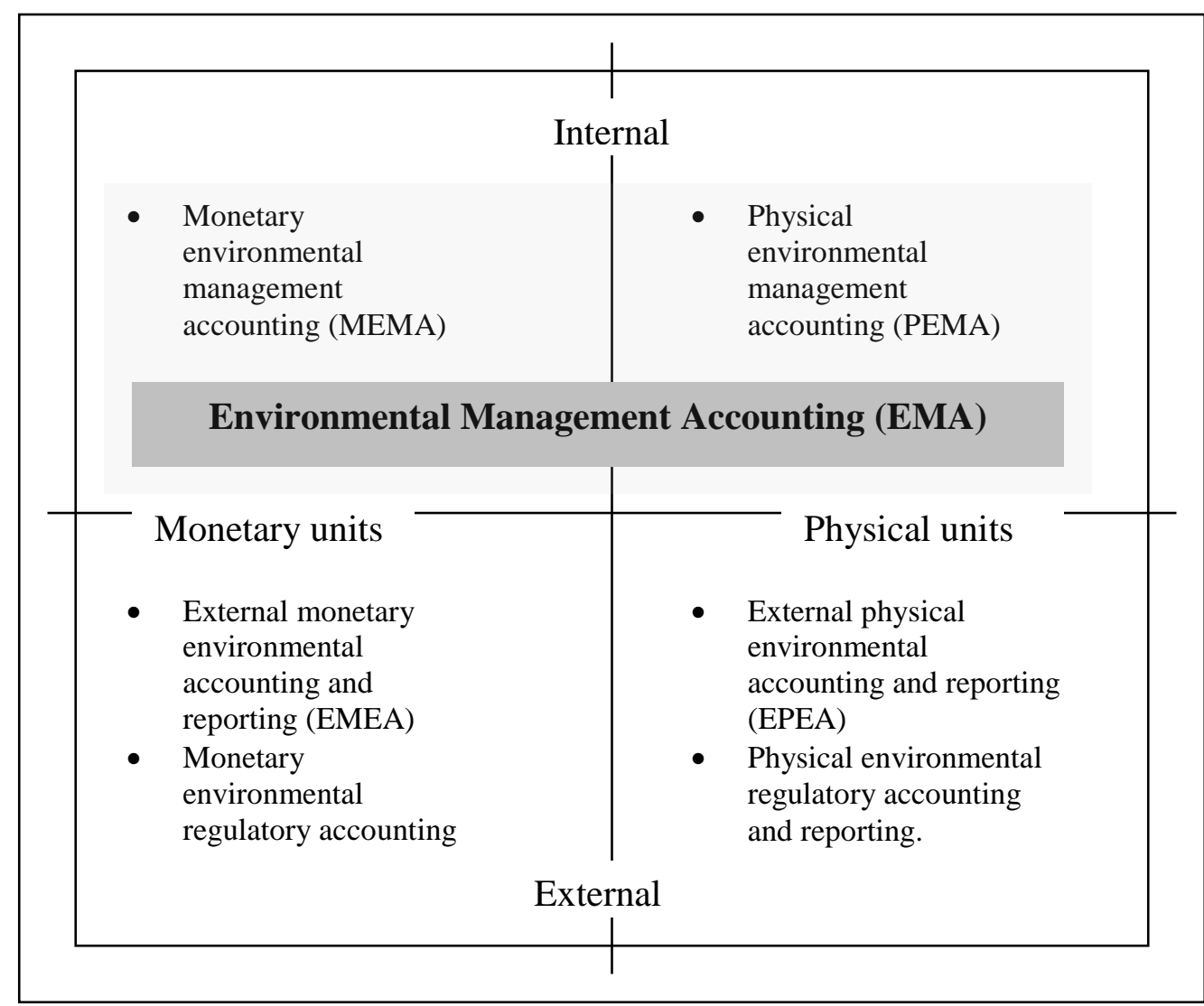

Sumber: Roger L Burrit, Tobias Hahn, dan Stefan Schaltegger. 2001. Current Developments in Environmental Management Accounting - Towards a Comprehensive Framework for Environmental Management Accounting.

\section{Gambar 6. Sistem Akuntansi Lingkungan}

Berdasarkan pemahaman mendasar mengenai akuntansi lingkungan, Burrit dkk (Burrit. dkk, 2001) dalam makalahnya menyatakan bahwa pendekatan sistem akuntansi lingkungan yang berbeda dapat diikutsertakan dalam kerangka kerja akuntansi lingkungan.

Akuntansi lingkungan moneter (monetary environmental accounting) meliputi:

1. Monetary environmental management accounting (MEMA) sebagai akuntansi lingkungan internal yang digambarkan dalam satuan uang.

2. External monetary environmental accounting (EMEA) sebagai akuntansi lingkungan esternal dan pelaporan yang diutarakan dalam satuan uang.

3. Akuntansi lingkungan moneter yang lain, seperti akuntansi pajak lingkungan.

Akuntansi lingkungan fisik (physical environmental accounting) meliputi: 
1. Physical environmental management accounting (PEMA) sebagai akuntansi lingkungan internal yang dinyatakan dalam satuan fisik

2. External physical environmental accounting (EPEA) sebagai akuntansi lingkungan eksternal dalam unit fisik.

3. Akuntansi lingkungan fisik yang lain.

Dalam hal metode yang digunakan, MEMA dilakukan berdasarkan akuntansi manajemen konvensional yang dikembangkan untuk aspek lingkungan dari aktivitas perusahaan. Hal ini berkaitan dengan dampak lingkungan yang disebabkan oleh perusahaan yang diukur dalam satuan uang. MEMA adalah sistem akuntansi yang berfokus pada dampak ekonomi terhadap aktivitas perusahaan yang berkaitan dengan lingkungan (a focus on the economic impacts of environmentally-induced corporate activities). PEMA berfokus pada dampak perusahaan terhdap lingkungan, dang dinyatakan dalam satuan fisik. Alat alat yang digunakan PEMA didesain untuk mengumpulkan dampak lingkungan dalam unit fisik untuk penggunaan internal perusahaan.

Tabel 1. meliputi semua dimensi yang terkait dengan EMA, yaitu internal vs eksternal, klasifikasi fisik vs moneter, rentang waktu masa lalu dan masa depan, dan pengumpulan informasi ad hoc vs rutin. Bagian yang masuk di dalam kategori berorientasi masa lalu dan masa depan membedakan antara alat alat MEMA dan PEMA yang digunakan oleh manajemen untuk menggambarkan isu lingkungan dengan fokus pengukuran transaksi masa lampau, atau prediksi transaksi di masa yang akan datang. Rentang waktu yang dibedakan menjadi jangka pendek dan jangka panjang membedakan antara alat-alat MEMA dan PEMA yang tersedia bagi manajemen untuk menggambarkan isu isu lingkungan yang memiliki fokus jangka panjang atau pendek. Informasi ad hoc dan informasi rutin membedakan antara alatalat MEMA dan PEMA yang tersedia bagi manajemen untuk menggambarkan isu-isu lingkungan yang rutin dan tidak rutin diperlukan. Tabel 2.2. menggambarkan bahwa EMA meliputi banyak pendekatan akuntansi yang memenuhi berbagai kebutuhan yang berbeda berdasarkan konteks keputusan yang akan diambil, tujuan, dan tingkat manajemen.

\section{Klasifikasi Biaya Lingkungan}

Biaya lingkungan adalah biaya yang muncul dalam usaha untuk mencapai tujuan seperti pengurangan biaya lingkungan, meningkatkan pendapatan, meningkatkan kinerja lingkungan yang perlu dipertimbangkan saat ini dan yang akan datang (Astuti, 2002: 59). Biaya lingkungan, atau disebut juga sebagai biaya kualitas lingkungan (environmental quality cost) adalah biaya-biaya yang terjadi karena adanya kualitas lingkungan yang buruk atau karena kualitas lingkungan yang buruk mungkin terjadi (Hansen \& Mowen, 2005:72). Dengan definisi ini, biaya lingkungan dapat diklasifikasikan menjadi empat kategori:

- Biaya pencegahan (environmental prevention cost)

- Biaya deteksi (environmental detection cost)

- Biaya kegagalan internal (environmental internal failure cost) 
- Biaya kegagalan eksternal (environmental external failure cost)

Produk dan proses merupakan sumber biaya lingkungan. Residu merupakan penyebab biaya kegagalan lingkungan, pengemasan juga merupakan sumber biaya lingkungan. Produk sendiri dapat menjadi sumber biaya lingkungan, Setelah menjual produk, penggunaan dan pembuangannya oleh pelanggan dapat mengakibatkan degradasi lingkungan. Biaya lingkungan pasca pembelian (environmental postpurchase cost) seringkali ditanggung oleh masyarakat, dan bukan oleh perusahaan, sehingga merupakan biaya sosial. Hansen dan Mowen menyatakan bahwa biaya lingkungan akan menerima perhatian manajerial hanya jika jumlahnya signifikan (Hansen \& Mowen, 2005:75-76). Menurut Ditz, proporsi biaya lingkungan adalah 20\% dari total biaya operasional perusahaan (Hansen \& Mowen, 2005: 76) 
Tabel 1. Kerangka Kerja EMA

\begin{tabular}{|c|c|c|c|c|c|}
\hline & \multicolumn{4}{|c|}{ Environmental Management Accounting (EMA) } \\
\hline & & \multicolumn{2}{|c|}{$\begin{array}{l}\text { Monetary Environmental Management } \\
\text { Accounting (MEMA) }\end{array}$} & \multicolumn{2}{|c|}{$\begin{array}{l}\text { Physical Environmental Management } \\
\text { Accounting (PEMA) }\end{array}$} \\
\hline & & Short term focus & Long term focus & Short term focus & Long term focus \\
\hline \multirow[t]{2}{*}{ 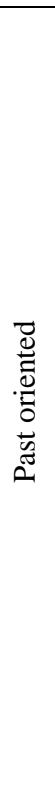 } & 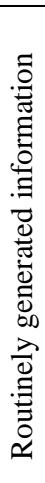 & $\begin{array}{l}\text { Environmental cost } \\
\text { accounting (e.g. } \\
\text { variable costing, } \\
\text { absorption costing, } \\
\text { and activity based } \\
\text { costing) }\end{array}$ & \begin{tabular}{l}
\multicolumn{2}{l}{ Environmentally } \\
induced capital \\
expenditure and \\
revenues
\end{tabular} & $\begin{array}{l}\text { Material and energy } \\
\text { flow accounting (short } \\
\text { term impacts on the } \\
\text { environment - product, } \\
\text { site, division, and } \\
\text { company levels) }\end{array}$ & $\begin{array}{l}\text { Environmental (or } \\
\text { natural) capital } \\
\text { impact accounting }\end{array}$ \\
\hline & 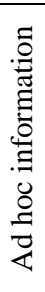 & $\begin{array}{l}\text { Ex post assessment } \\
\text { of relevant } \\
\text { environmental } \\
\text { costing decisions }\end{array}$ & $\begin{array}{l}\text { Environmental life } \\
\text { cycle (and target) } \\
\text { costing } \\
\text { Post investment } \\
\text { assessment of } \\
\text { individual projects }\end{array}$ & $\begin{array}{l}\text { Ex post assessment of } \\
\text { short term } \\
\text { environmental impacts } \\
\text { (e./g. of a site or } \\
\text { product) }\end{array}$ & $\begin{array}{l}\text { Life cycle } \\
\text { inventories } \\
\text { Post investment } \\
\text { assessment of } \\
\text { physical } \\
\text { environmental } \\
\text { investment appraisal }\end{array}$ \\
\hline \multirow{2}{*}{ 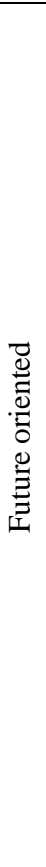 } & 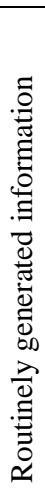 & $\begin{array}{l}\text { Monetary } \\
\text { environmental } \\
\text { operational } \\
\text { budgeting (flows) } \\
\text { Monetary } \\
\text { environmental } \\
\text { capital budgeting } \\
\text { (stocks) }\end{array}$ & $\begin{array}{l}\text { Environmental } \\
\text { long term financial } \\
\text { planning }\end{array}$ & $\begin{array}{l}\text { Physical environmental } \\
\text { budgeting (flows and } \\
\text { stocks) (e.g. material } \\
\text { and energy flow } \\
\text { activity based costing) }\end{array}$ & $\begin{array}{l}\text { Long term physical } \\
\text { environmental } \\
\text { planning }\end{array}$ \\
\hline & 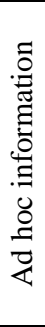 & $\begin{array}{l}\text { Relevant } \\
\text { environmental } \\
\text { costing (e.g. special } \\
\text { orders, product mix } \\
\text { with capacity } \\
\text { constraint) }\end{array}$ & $\begin{array}{l}\text { Monetary } \\
\text { environmental } \\
\text { projects } \\
\text { investment } \\
\text { appraisal } \\
\text { Environmental life } \\
\text { cycle budgeting } \\
\text { and target pricing }\end{array}$ & $\begin{array}{l}\text { Relevant } \\
\text { environmental impacts } \\
\text { (e.g. given short run } \\
\text { constraints on } \\
\text { activities) }\end{array}$ & $\begin{array}{l}\text { Physical } \\
\text { environmental } \\
\text { investment appraisal } \\
\text { Life cycle analysis } \\
\text { of specific project. }\end{array}$ \\
\hline
\end{tabular}

Sumber: Roger L Burrit, Tobias Hahn, dan Stefan Schaltegger. 2001. Current Developments in Environmental Management Accounting - Towards a Comprehensive Framework for Environmental Management Accounting. 
Selain itu, juga ada pendekatan yang menyatakan bahwa biaya akuntansi internal terdiri dari tiga macam biaya lingkungan, yaitu biaya langsung, biaya tidak langsung, dan biaya kontijensi (Gale, 2001). Biaya internal biasanya diestimasi dan dialokasikan dengan menggunakan model biaya standar. Biaya langsung dapat ditelusuri pada produk, lokasi, tipe polusi, atau program pencegahan polusi. Biaya tidak langsung seperti pelatihan lingkungan, riset dan pengembangan, dialokasikan ke dalam pusat biaya seperti produk, departemen, atau aktivitas. Biaya kontingensi adalah biaya yang bisa terjadi di masa depan yang berpengaruh bagi perusahaan. Biaya kontinjensi dibedakan menjadi dua macam, yaitu internal dan eksternal. Biaya kontinjensi meliputi: perubahan di dalam kualitas produk sebagai akibat adanya perubahan ketentuan yang mempengaruhi input, metode produksi, atau emisi yang diperbolehkan.biaya kontijensi juga meliputi kepuasan dan kesehatan karyawan, persepsi konsumen dan biaya hubungan.

Di dalam publikasi mengenai EMA yang berjudul Environmental Management Accounting: Procedures and Principles (United Nations Division of Sustainable Development, 2001) dijelaskan mengenai klasifikasi biaya dan pendapatan lingkungan dengan pendekatan yang berbeda. Di dalam pendekatan ini, biaya dan pendapatan lingkungan dikelompokkan menjadi 5 bagian sebagai berikut:

1. Waste and emmision treatment.

Biaya pengolahan limbah dan emisi harus didistribusikan ke dalam media lingkungan yang berbeda. Pengumpulan limbah, daur ulang, dan biaya pembuangan adalah biaya yang paling muda untuk diamati. Yang termasuk di dalam kategori biaya tersebut adalah:

a. Depreciation for related equipment

Perhitungan depresiasi alat-alat yang dimaksudkan di sini adalah peralatan, mesin-mesin yang dalam operasinya berkaitan dengan pengelolaan limbah yang dihasilkan oleh perusahaan.

b. Maintenance and operating materials and services

Biaya yang termasuk adalah biaya yang berkaitan dengan perawatan peralatan dan pengoperasian peralatan yang berkaitan dengan pengelolaan limbah.

c. Related personnel

Biaya yang termasuk di dalam kategori ini adalah gaji karyawan yang bekerja dalam penanganan limbah perusahaan, dan orang-orang yang bertanggung jawab mengenai limbah, dan berkaitan langsung dengan aliran limbah dan emisi, dan peralatan pengelolaan limbah.

d. Fees, taxes, charges

Semua proses pembuangan, perijinan yang diperoleh perusahaan, dan pajak lingkungan harus dimasukkan di dalamnya. Dalam hal output, pajak dan 
biaya juga dikeluarkan oleh perusahaan berdasarkan volume limbah ataupun limbah cair, dan emisi udara.

e. Fines and penalties

Denda dan penalti dikenakan kepada perusahaan apabila ada pelanggaran yang dilakukan oleh perusahaan.

f. Insurance for environmental liabilities

Perusahaan dapat memiliki asuransi yang melindungi perusahaan dari berbagai resiko. Asuransi yang berkaitan dengan lingkungan adalah resiko kerusakan pada barang-barang, dan manusia yang disebabkan oleh aktivitas berbahaya yang berkaitan dengan lingkungan

g. Provisions for clean up costs, remediation

Fungsi provision adalah untuk mengantisipasi kewajiban di masa depan, dan membantu perusahaan melindungi dirinya dari kewajiban kontijensi yang mungkin timbul apabila terjadi pencemaran lingkungan oleh perusahaan.

2. Prevention and environmental management, yang terdiri atas:

a. External services for environmental management

Semua jasa eksternal seperti konsultan yang berkaitan dengan lingkungan, pelatihan, inspeksi, audit, dan komunikasi harus dimasukkan di dalam kategori ini.

b. Personnel for general environmental management activities

Bagian ini meliputi karyawan perusahaan yang bertugas dalam aktivitas pengelolaan lingkungan, yang tidak secara langsung berkaitan dengan pengolahan limbah, ataupun produksi output non produk. Jam kerja untuk program pelatihan meliputi biaya perjalanan, aktivitas dan proyek manajemen lingkungan, audit, dan komunikasi harus diperhitungkan juga.

c. Research and development

Kontrak esternal dan jam kerja staf internal untuk penelitian dan pengembangan harus dipisahkan dari aktivitas manajemen lingkungan yang bersifat umum karena jumlahnya bisa memiliki perbedaan yang sangat substansial untuk tiap periode.

d. Extra expenditure for cleaner technologies

Jika ada perbedaan signifikan dalam biaya investasi yang dilakukan oleh perusahaan dan investasi tersebut dilakukan untuk memenuhi tujuan perlindungan lingkungan, maka pengeluaran tersebut dapat dimasukkan ke dalam kategori ini.

e. Other environmental management costs

Bermacam-macam biaya yang berkaitan dengan perlindungan lingkungan dapat dimasukkan ke dalam kategori ini. Porsi utama dari kategori ini berkaitan dengan komunikasi eksternal yang dilakukan oleh perusahaan. 
3. Material purchase value of non-product output (NPO), yang terdiri atas:

a. Raw materials

Yang dijadikan sebagai estimasi awal adalah kalkulasi internal mengenai proporsi (presentase) bahan sisa setelah proses produksi yang dapat digunakan untuk emngestimasikan NPO yang berupa bahan mentah.

b. Packaging

Kemasan produk sebagian besar meninggalkan perusahaan bersama sama dengan produk, namun ada juga yang tidak keluar bersama produk karena ada pengemasan ulang untuk tempat tujuan tertentu, dan ini juga perlu diestimasi jumlahnya.

c. Auxilary materials

Bahan bahan yang termasuk di dalamnya adalah bahan bahan yang menjadi bagian dari produk namun bukan menjadi komponen yang penting.

d. Operating materials

Perlu dibedakan antara bahan operasi yang digunakan di dalam proses produksi dan yang digunakan untuk kepentingan adminstratif.

e. Energy

Untuk input energi, proporsi energi yang tidak efisien di dalam proses produksi ditentukan oleh manajer produksi. Bagian ini kemudian diperhitungkan dengan harga pembelian energi tersebut.

f. Water

Nilai pembelian air dimasukkan ke dalam kategori ini, namun untuk industri tertentu yang di dalam produknya terdapat air, maka yang diperhitungkan di dalam kategori ini adalah persentase air yang terbuang.

4. Processing costs of non-product output (NPO)

Output selain produk yang dihasilkan perusahaan tidak saja memiliki nilai pembelian, namun juga melalui proses produksi, sehingga biaya produksi juga harus diperhitungkan. Waktu kerja yang hilang karena inefisiensi produksi dan sebagian nilai depresiasi mesin dan juga biaya lain perlu untuk dimasukkan di dalam kategori biaya ini.

5. Environmental revenues

a. Subsidies, awards

Perusahaan bisa jadi memperoleh penghargaan dan subsidi dari pemerintah apabila telah mematuhi ketentuan.

b. Other earnings

Pendapatan dari hasil penjualan limbah dapat dimasukkan ke dalam kategori ini.

Biaya lingkungan tersebut dikelompokkan ke dalam beberapa media lingkungan (environmental media) yang terdiri atas: (a). air/climate, (b). wastewater, (c). waste, $(d)$. soil/groundwater, (e). noise/vibration, $(f)$. biodiversity/landscape, (g). radiation, dan (h). other.

Klasifikasi media lingkungan ini disusun berdasarkan terbitan United Nations Statistic Division yang berjudul Integrated Environmental and Economic Accoutning: 
Handbok of National Accounting (SEEA) pada tahun 1993 (United Nations Division for Sustainable Development, 2001: 14). Media lingkungan tersebut mewakili kategori dampak lingkungan yang ditimbulkan terhadap alam.

Biaya lingkungan harus diukur dengan menggunakan checklist yang terpisah dimana yang pertama dilakukan oleh controller yang mengidentifikasi pengeluaran lingkungan untuk tiap kategori biaya sementara manajer lingkungan menghitung biaya yang dikeluarkan untuk tiap media lingkungan (United Nations Division for Sustainable Development, 2001: 15). Kemudian kedua checklist tersebut dibandingkan agar dapat memperoleh gambaran mengenai kinerja lingkungan yang sudah dilakukan oleh perusahaan. 


\section{Tabel 2. Environmental Expenditure/Costs and Revenue/Earnings}

\begin{tabular}{|c|c|c|c|c|c|c|c|c|c|}
\hline $\begin{array}{l}\text { Environmental cost/expenditure } \\
\text { categories }\end{array}$ & 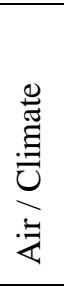 & 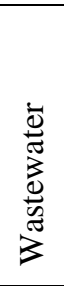 & $\begin{array}{l}\frac{\mathbb{v}}{\tilde{a}} \\
\overrightarrow{3}\end{array}$ & 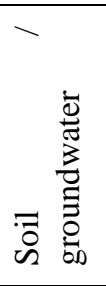 & 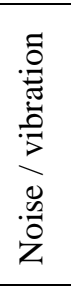 & 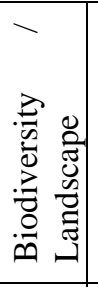 & 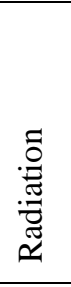 & $\begin{array}{l}\overline{0} \\
\stackrel{ \pm}{0}\end{array}$ & $\stackrel{\pi}{0}$ \\
\hline \multicolumn{10}{|l|}{ 1. Waste and emission treatment } \\
\hline \multicolumn{10}{|l|}{ 1.1. Depreciation for related equipment } \\
\hline \multicolumn{10}{|l|}{$\begin{array}{l}\text { 1.2. Manitenance and operating materials } \\
\text { and services }\end{array}$} \\
\hline \multicolumn{10}{|l|}{ 1.3. Related Personnel } \\
\hline \multicolumn{10}{|l|}{ 1.4. Fees, taxes, charges } \\
\hline \multicolumn{10}{|l|}{ 1.5. Fines and penalties } \\
\hline \multicolumn{10}{|l|}{$\begin{array}{l}\text { 1.6. Insurance for environmental } \\
\text { liabilities }\end{array}$} \\
\hline \multicolumn{10}{|l|}{$\begin{array}{l}\text { 1.7. Provisions for clean up costs, } \\
\text { remediation }\end{array}$} \\
\hline \multicolumn{10}{|l|}{$\begin{array}{l}\text { 2. Prevention and environmental } \\
\text { management }\end{array}$} \\
\hline \multicolumn{10}{|l|}{$\begin{array}{l}\text { 2.1. External services for environmental } \\
\text { management }\end{array}$} \\
\hline \multicolumn{10}{|l|}{$\begin{array}{l}\text { 2.2. Personnel for general environmental } \\
\text { management activities }\end{array}$} \\
\hline \multicolumn{10}{|l|}{ 2.3. Research and development } \\
\hline \multicolumn{10}{|l|}{$\begin{array}{l}\text { 2.4. Extra expenditure for cleaner } \\
\text { technologies }\end{array}$} \\
\hline \multicolumn{10}{|l|}{$\begin{array}{l}\text { 2.5. Other environmental management } \\
\text { costs }\end{array}$} \\
\hline \multicolumn{10}{|l|}{$\begin{array}{l}\text { 3. Material purchase value of non- } \\
\text { product (output }\end{array}$} \\
\hline \multicolumn{10}{|l|}{ 3.1. Raw materials } \\
\hline \multicolumn{10}{|l|}{ 3.2. Packaging } \\
\hline \multicolumn{10}{|l|}{ 3.3. Auxiliary materials } \\
\hline \multicolumn{10}{|l|}{3.4 Operating Materials } \\
\hline \multicolumn{10}{|l|}{ 3.5. Energy } \\
\hline \multicolumn{10}{|l|}{ 3.6. Water } \\
\hline \multicolumn{10}{|l|}{$\begin{array}{l}\text { 4. Processing costs of non-product } \\
\text { output }\end{array}$} \\
\hline \multicolumn{10}{|l|}{ E Environmental expenditures } \\
\hline \multicolumn{10}{|l|}{ 5. Environmental revenues } \\
\hline \multicolumn{10}{|l|}{ 5.1. Subsidies, awards } \\
\hline \multicolumn{10}{|l|}{ 5.2. Other earnings } \\
\hline$\sum$ Environmental revenues & & & & & & & & & \\
\hline
\end{tabular}


Sumber: United Nations Division for Sustainable Development. 2001. Environmental

Management Accounting Procedures and Principles. New York. United Nations. Hal. 19

\section{SIMPULAN}

Berdasarkan pembahasan yang telah disajikan pada bab terdahulu, maka simpulan ini adalah sebagai berikut:

1. Biaya lingkungan dibagi ke dalam empat kategori yaitu waste and emission treatment, prevention and environmental management, material purchase value of non-product output, dan processing costs of non-product output. Kategori biaya lingkungan yang memiliki nilai paling besar adalah material purchase value of non-product output dan yang terkecil adalah kategori prevention dan environmental management.

2. Perusahaan seharusnya melakukan upaya pengolahan limbah meskipun itu hanya untuk limbah cair, sedangkan untuk limbah padat dijual.

\section{DAFTAR PUSTAKA}

Astuti, Sri dan Ichsan. 2002. Akuntansi Biaya Lingkungan: Suatu Konsep dan Permasalahannya. Media Akuntansi. Edisi 28: 58-62.

Bartolomeo, Matteo, Martin Bennet, Jan Jaap Bourma, Peter Heydkamp, Peter James, dan Teun Wolters. 2000. Environmental Management Accounting in Europe: Current Practice and Future Potential. The European Accounting Review. Vol 9: 31-52.

Burrit, Roger L, Tobias Hahn, dan Stefan Schaltegger. 2001. Current Developments in Environmental Management Accounting - Towards a Comprehensive Framework for Environmental Management Accounting http//:www.unilueneburg.de/eman/pdf_dateien/Burritt-Hahn.pdf

Chandra, Laurentia Alice. 2006. Analisis Manajemen Biaya Lingkungan sebagai Respon terhadap Perolehan Sertifikasi ISO 14001:2004 pada PT Hari Terang (Baterai ABC) di Surabaya. Skripsi

Cahyono, Dwi. 2002. Peran Akuntan dan Akuntansi dalam Environmental Management System (EMS). Media Akuntansi. Edisi 25: 27-29.

Environmental Protection Agency (EPA). 1995. An Introduction to Environmental Accounting As a Business management Tool: Key concepts and Terms. Washington DC. Office of Pollution Prevention and Toxic.

Gale, Robert J P dan Peter K Stokoe. 2001. Environmental Cost Accounting and Business Strategy. Handbook of Environmentally Conscious Manufacturing. Kluwer Academic Publisher.

Gray, Rob \& Jan Bebbington. 2001. Accounting for the Environment, $2^{\text {nd }}$ edition. London. Sage Publication. 
Graff, Robert G, Edward D Reiskin, Allen L White, dan Katherine Bidwell. 1998. Snapshots of Environmental Cost Accounting. Boston. Tellus Institute.

Hansen, Don R \& Maryanne M Mowen. 2007. Akuntansi Manajemen, Buku 1. Edisi ketujuh. Terjemahan. Jakarta: Salemba Empat.

. 2007. Akuntansi Manajemen, Buku 2. Edisi ketujuh. Terjemahan. Jakarta: Salemba Empat.

Hamid, Mohamed A Raouf A. 2002. Theoretical Framework for Enviromental Accounting-Application on the Egyptian Petroleum Sector. Cairo. The Egyptian Forum on Environment \& Sustainable Development (EFESD)

International Federation of Accountants. 2005. International Guidance Document, Environmental Management Accounting. New York. IFAC

Sunu, Pramudya. 2001. Melindungi Lingkungan dengan Menerapkan ISO 14001. Jakarta. Grasindo.

United Nations Division for Sustainable Development. 2001. Environmental Management Accounting Procedures and Principles. New York. United Nations.

Verfaillie, Hendrik A, Robin Bidwell.. 2000. Measuring Eco-Efficiency, A Guide to Reporting Company Performance. World Business Council for Sustainable Development

Xiaomei, Li. 2004. Theory and Practice of Environmental Management Accounting, Experience of Implementation in China. International Journal of Technology Management and Sustainable Development. Vol 3: 47-58. 